\title{
Designing the Emergency Online Study Bubble
}

\author{
Emre Erturk $^{1 *}$ and Samuel Ekundayo ${ }^{2}$ \\ ${ }^{1}$ Eastern Institute of Technology New Zealand, Hawke's Bay Campus \\ ${ }^{2}$ Eastern Institute of Technology New Zealand, Auckland Campus
}

\section{Abstract}

In 2020, although many students around the world are studying online from home as a result of the COVID-19 global pandemic, this situation is quite different from ordinary online study. For example, in the past, most students studying online would have still had access to campus or education centre resources, face-to-face advisors, or libraries. This research has been conducted at a New Zealand institution of higher learning, which has had to adapt quickly to these special circumstances. The researchers were actively teaching courses face-to-face prior to the lockdown; although there already were well-designed course sites, they have had to go from a blended course delivery to a completely online and isolated study mode.

The current literature is already resourceful in discussing the range of technologies, different levels of using learning management systems, and the variety of instructional strategies used within e-learning. However, these accounts are of a mechanical nature and tend to look at individual pieces either on their own or as a progression, rather than looking at the learning technology environment holistically.

This practical research paper is informed by reflection and concrete evidence collected while working with students remotely. There are three aims: (1) To qualitatively explore how far this team has successfully pushed their learning management systems and technologies to completely online learning, (2) To note and recommend for future research some the challenges involved including technical ones, security, and teaching staff workload, and (3) To demonstrate how the different teaching and learning elements and tools complement each other to form a digital study bubble that can be sustained.

During the semester, the researchers shared a Student Engagement Matrix, which documents the teaching staff and the students' participation in the Learning Management System (Moodle) and other tools that are used alongside the online courses, including live class sessions and meetings. The matrix columns are the levels of online engagement, the description or criteria for each level, and the third column for the evidence and comments. This paper summarizes and presents these findings. Finally, it concludes with recommendations for other practitioners and researchers.

\section{Keywords: E-learning Strategies, Student Support, Home Learning, Educational Technology}

Received on DD MM YYYY, accepted on DD MM YYYY, published on DD MM YYYY

Copyright (C) YYYY Author et al., licensed to IJMSTA. This is an open access article distributed under the terms of the Creative Commons Attribution licence (http://creativecommons.org/licenses/by/3.0/), which permits unlimited use, distribution and reproduction in any medium so long as the original work is properly cited.

doi: $10.4108 /$

*Corresponding author. eerturk@eit.ac.nz

\section{Introduction}

In 2020, many students around the world have been studying online from home as a result of the COVID-19 global pandemic and the public restrictions. However, this situation is quite different from ordinary online study, whereby most students studying online would still have access to campus or education centre resources, face-to-face advisors, or libraries. This research has been conducted at a New Zealand institution of higher learning, which has adapted quickly to the circumstances. As in other countries, during the last two decades, New Zealand governments have made investments in technology for schools and for online 
education [7]. The researchers were actively teaching courses face-to-face prior to the lockdown. Although there already were well-designed course sites, they had to go from a blended course delivery to a completely online and isolated study mode.

\section{Research Approach}

Looking at multiple cases (i.e. courses) in this article has the potential to provide more qualitative information and explanations of course design phenomena. The objective here is not to compare the courses but to explore the different ways that lecturers can enhance their courses. To be able to systematically group the information and identify similarities and themes, the authors have used a Student Engagement Matrix. This was inspired by previous articles such as [10]. It documents the teaching staff and the students' participation in the Learning Management System (Moodle) and other tools that are used alongside the online courses, including live class sessions and meetings.

\begin{tabular}{|c|c|c|}
\hline $\begin{array}{l}\text { Levels of Online } \\
\text { Engagement }\end{array}$ & Criteria & $\begin{array}{l}\text { Evidence and } \\
\text { Comments }\end{array}$ \\
\hline Level 1 & $\begin{array}{l}\text { Document and } \\
\text { Content Provision }\end{array}$ & $\begin{array}{l}\text { Confirm and } \\
\text { comment on the } \\
\text { extent and the } \\
\text { nature of what is } \\
\text { provided }\end{array}$ \\
\hline Level 2 & $\begin{array}{l}\text { Provision of } \\
\text { Grades and } \\
\text { Feedback to } \\
\text { Students }\end{array}$ & $\begin{array}{l}\text { Confirm and } \\
\text { comment on how } \\
\text { and/or how much } \\
\text { information is } \\
\text { provided }\end{array}$ \\
\hline Level 3 & $\begin{array}{l}\text { Evaluated } \\
\text { activities done } \\
\text { online (other than } \\
\text { report } \\
\text { submissions) }\end{array}$ & $\begin{array}{l}\text { Formative and/or } \\
\text { graded } \\
\text { discussion } \\
\text { forums, quizzes, } \\
\text { tests... }\end{array}$ \\
\hline Level 4 & $\begin{array}{l}\text { Recorded and/or } \\
\text { live class sessions } \\
\text { and meetings }\end{array}$ & $\begin{array}{l}\text { Confirm and } \\
\text { comment on the } \\
\text { extent or agenda }\end{array}$ \\
\hline Synergies & $\begin{array}{l}\text { Hypothesis: The } \\
\text { different types of } \\
\text { approaches above } \\
\text { are tied to and } \\
\text { support each other }\end{array}$ & $\begin{array}{l}\text { Your comments } \\
\text { and examples }\end{array}$ \\
\hline Issues & $\begin{array}{l}\text { Level } 3 \text { and } 4 \\
\text { activities present } \\
\text { challenges: } \\
\text { technical, security, } \\
\text { workload... }\end{array}$ & $\begin{array}{l}\text { Your comments } \\
\text { and examples }\end{array}$ \\
\hline
\end{tabular}

This practical research paper is based on reflection and concrete evidence collected while working with students remotely. The three aims are: (1) to qualitatively explore how well the team has used the learning systems and technologies to completely online learning, (2) to note and recommend for future research some the challenges involved including technical ones, security, and teaching staff workload, and (3) to demonstrate how the different teaching and learning elements and tools complement each other to form a digital study bubble that can be sustained.

\section{Literature Review}

The academic literature on online learning is quite rich. It is not the intent of these researchers to do an extensive review. There are a few examples that have been used here as practical references. Authors in [1] offer a list of technologies involved in e-Learning, as well as a list of instructional strategies. Interesting complementary technologies and learning objects include: multimedia, drawing tools, discussion areas, forums, augmented/virtual reality, learner journals, video conferencing, and glossaries. Relevant learning approaches and activities include problem solving, role playing, reflection, collaboration, scaffolding, and curation, among others - whereby students learn by doing and construct knowledge. Moodle (a popular Learning Management System software) can help facilitate many of these active and constructivist learning approaches [8].

There are also interesting and subtle in the literature that deserve attention. Note taking, which is a common practice in face-to-face learning, is often neglected or not effectively addressed in online courses [4]. Communicating task requirements and time on task is one of the Seven Principles for Good Practice in Undergraduate Education formulated by Chickering and Gamson in 1987 as cited in [2]. According to [9], student group work plays a significant role in online education, and accountability toward groups may also have benefits in terms of attendance and encouraging progress on assignments. Two other subtle points are related to some of the practices in Universal Design for Learning. It is important to begin a lesson with an outline of what will be covered, and to conclude each lesson with a summary [5]. In contrast to the various practical teaching tips and technologies mentioned above, the researchers have decided to look at the whole situation in a real-world example.

\section{Discussion of the Cases}

\subsection{Online Course Module: ITPG8.600}

This course (Advanced Mobile and Wireless Technologies) included PowerPoint slides to convey the ongoing contents of the course. These were also used every week during the Zoom video conference sessions with the students. Furthermore, some slides required students to do activities that required them to pause, contemplate, and share their experiences and knowledge with the class online. Students themselves also made presentations with slides via Zoom. 
The topics were handed out in advance, and they presented in groups of two, which also made it rather different and interesting. The student presentations sometimes also involved role playing, e.g. as sponsors, evaluators, and project managers.

The students worked on the assignment in groups and were able to collaborate to prepare their presentation before the class. Several weekly activities required students to solve real world problems together. The lecturer also asked them three questions online about their work in the group to help them reflect.

The course site featured video content when necessary to help cover the learning outcomes. The lecturer also encouraged students to share videos with their presentations. In one of the sessions, the students would send YouTube links ahead of time for some topics of discussion, which the lecturer would vet to make sure they are relevant and then shared during the session with the rest of the students. The class then had a scholarly conversation about the video and the topic. This helped the students to be active and also to engage in the lessons, and not only that it provided an avenue for them to take control of their learning in and outside the classroom.

Discussion forums were used for four purposes:

- Platform for student reflection: Every week the students reflected on and discussed what they learned.

- Platform for formative assessment: The students had the forums as a homework task that complemented the learning outcomes for the week.

- Collaboration and engagement: The students saw the forums as platforms to engage each other, learn from each other, and also collaborate with each other.

- Receiving student feedback: This helped see areas that may be improved in terms of the lecturer's own teaching and content. The lecturer was also able to see which concepts or instructions the students may not be understanding and therefore offer help as needed.

Zoom also has a whiteboard feature. The lecturer used this to illustrate some of the content. There are some ideas that are better illustrated on a whiteboard and this feature of the video software came in handy. I also used the Zoom breakout rooms to put students in groups for them to discuss contents of the course. I am able to access each room to assess what students were discussing and to offer assistance when necessary.

During the sessions, the lecturer provided weekly feedback to students on their work. Where students had to work within groups, the lecturer asked them three questions: what went well this week, what did not go well, and what would you do differently. These questions often create a pattern of reflection for the members of the group and allows the lecturer to assess their progress and provide help where necessary.

Written feedback was provided for written assignments and reports. The students were asked to submit drafts of their summative assessments weekly. This may seem tiring, but because of the lockdown, it was necessary. The lecturer was then able to track their progress and effectively assist them. Feedback was provided before the assessment due date so that they would have adequate time to address any concerns or shortfalls. Students also get their final grades on Moodle together with Turnitin. The discussion forums were also a way of giving feedback to students.

The students reflected on their learnings on an ongoing basis. The lecturer had the students submit reviews of the scholarly articles they were reading every week. The lecturer commented on the reviews and also got fellow students to comment and ask questions. This kept the students active throughout the course and helped to assess and keep track of their progress in the course.

All Zoom sessions were recorded. The Zoom Cloud platform hosted most of the session recordings. After every class, the lecturer posted the links to the Moodle pages so they could watch the lecture again when necessary.

Overall, this course has clearly operated at all of the four levels in the Student Engagement Matrix.

\subsection{Online Course Module: Programme Site}

This course is open to all the students in the same programme who are studying in Master's level Information Technology courses. The purpose of the course is to keep everyone informed about academic matters and to help create a social bond. The information and resources contained within this module is important to student wellbeing and the formation of a study bubble. This Moodle module (along with a Facebook page) has been used during the lockdown (March-June) to supplement the operation of all the regular subject specific courses.

The first communication in March was to inform students that the courses moved to fully online mode, and to remind them to regularly check the updates and announcements in all of their courses. The second detailed communication in March was to make students aware of online library resources for scholarly and technical reading material (both internal and external on the Internet). Similarly, communication was distributed on how to download Microsoft products freely for the students. At the same time, there was also an online chess club announcement for those wanting to engage in this type of activity during the period when everyone was required to stay at home.

At the beginning of April, a LinkedIn networking group was also activated. It was necessary to do a survey to feel the pulse of the students and to reach out to those who may potentially need personal help. An Augmented Reality mobile app was created to run this as a friendly game and also to illustrate this software to Information Technology students. Furthermore, a digital sticky wall was created and shared publicly for students to share their feelings and even funny pictures and jokes about technology. This was done with the purpose of helping to maintain student morale. Another important development in April was the recruitment of student/peer mentors to look after other students, especially for relatively recent international students. 
The following month (May) began with communications related to the students' future terms/semesters and to check which courses they had enrolled after June. In early June, students were invited again to follow the institute's general social media accounts on Facebook, Instagram and YouTube. This has also kept the students engaged and as part of the larger campus community.

Table 1 gives a brief snapshot of the timeline of this module during the lockdown. In summary, the main roles of the second module discussed in this section has been to complement the regular courses such as the first case study in section 4.1 and contribute to the quality of the overall learning environment.

\subsection{Analysis}

This section returns to the researcher's original aims. They will continue to work on these aims and on answering these research questions. However, this section briefly summarizes the progress so far. From the cases discussed above, it can be seen that the online learning system was used very frequently with good participation. Other technologies were effectively linked to satisfy and expand the learning experience.

The first of the challenges has been related to staff workload, as a result of preparing new resources and activities. This was recognised also by other authors [6] who provided examples of additional tasks such as searching for new content to share, managing additional communications, recording lectures, and so on. Authors in [3] also mention the importance of a healthy work-life balance for teaching staff. For the case study institute, one security concern to be kept in mind was possibly unexpected attendees in Zoom sessions who might do something disruptive. Therefore, the staff have closely monitored attendance in their sessions, using the session admission and muting controls as may be needed. Another emerging technical concern is the growing size of digital storage space needed for all the new videos and other content. As a result, the institute's technical staff have set up and been managing more storage cloud services.

Finally, it was important for this study to understand how different teaching and learning elements and tools complement each other and work synergistically in a digital study bubble. It is important for each course to offer a whole variety of learning activities and technologies. At the same time, there needs to be additional online areas (such as the one discussed in Section 4.2) where there are additional resources, applications, forums, and social links.

\section{Conclusion}

The pandemic of 2020 has accelerated the development of online education, not only quantitatively, but also in terms of the higher quality with which it can be implemented.
Table 1. Summary of Student Communications For the Programme Site

\begin{tabular}{lll}
\multirow{2}{*}{ Month } & Main Goals & Technologies \\
\cline { 2 - 3 } & Practical & Moodle and \\
April & Support & Online Libraries \\
& Student & Augmented Reality \\
May/June & $\begin{array}{l}\text { Expression } \\
\text { Community } \\
\text { Involvement }\end{array}$ & Mobile App, Graphics \\
& & Social Media \\
\hline
\end{tabular}

In this paper, the student's environment has been called a bubble due to the word 'bubble' being used to indicate isolation within a home alone or with a small group of people. Studying in a bubble can sometimes be almost like studying in a virtual reality. Therefore, it is important for students to enjoy this environment with multiple types of activities and social approaches.

The literature review is not conclusive as many new studies and changing of practices are underway in 2020. Therefore, there are certain notable directions for future research about digital environments, pedagogy, and educational technology. More research needs to be done regarding Virtual and Augmented Reality applications that are expected to be used at home for formal learning, rather than at schools and classrooms. The next desirable step in live sessions is one where all students see each other, rather than mainly using audio or messaging. Therefore, educational leaders need to help remedy situations where students cannot afford or do not have the sufficient internet connection and the modern equipment. In terms of convenience, mobile education seems more feasible and more application development and research can be done in this area.

\section{References}

[1] Aparicio, M., Bacao, F., \& Oliveira, T. (2016). An eLearning Theoretical Framework. Educational Technology \& Society, 19 (1), 292-307.

[2] Baldwin, S., \& Trespalacios, J. (2017). Evaluation instruments and good practices in online education. Online Learning 21(2).

[3] Cooper, L., Laster-Loftus, A., \& Mandernach, B. (2019). Efficient Online Instruction: Maximum Impact in Minimal Time. Online Journal of Distance Learning Administration, 22(3).

[4] Cushard, B. (n.d.). Note-taking and E-learning: Lessons for Learners and LX Designers. https://mindflash.com/blog/note-taking-and-e-learninglessons-for-learners-and-lx-designers

[5] Davies, P. L., Schelly, C. L., \& Spooner, C. L. (2013). Measuring the effectiveness of universal design for learning intervention in postsecondary education. Journal of Postsecondary Education and Disability, 26(3), 195-220. 
[6] Dwevedi, A., Sengar, A. e Solanki, M. (2019). Analysis of time investment in outline teacher: Log diary approach. In Proceedings of the 3rd. International Conference in Digital Technology in Education. Yamanashi, Japan.

[7] Erturk, E., \& Fail, D. (2013). Information technology in New Zealand: Review of emerging social trends, current issues, and policies. Journal of Emerging Trends in Computing and Information Sciences, 4(1), 46-52.

[8] Finnegan, M. and Ginty, C. (2019). Moodle and Social Constructivism: Is Moodle Being Used as Constructed? A Case Study Analysis of Moodle Use in Teaching and Learning in an Irish Higher Educational Institute. All Ireland Journal of Teaching and Learning in Higher Education, 11(1).

[9] Hubbard, R. S. (2015). Student Outcomes and Retention in Online Academic and Training Programs. In Keengwe, J., \& Agamba, J. J. (eds.), Models for Improving and Optimizing Online and Blended Learning in Higher Education (pp. 147-172). (Hershey: IGI Global), ch. 8.

[10] Janossy, J. (2008). Proposed Model for Evaluating C/LMS Faculty Usage in Higher Education Institutions. 13th Annual Instructional Technology Conference. Murfreesboro: Middle Tennessee State University. 